\title{
INFLUENCE OF SELECTED FEATURES OF FORESTS ON FOREST LANDSCAPE AESTHETIC VALUE - EXAMPLE OF SE POLAND
}

\author{
Tomasz DUDEK ${ }^{*}$ \\ Department of Agroecology, University of Rzeszów ul. Ćwiklińskiej 1, PL-35-601, Rzeszów, Poland
}

Received 22 March 2017; accepted 09 April 2018

\begin{abstract}
The study was designed to examine the relationship between features of forests and the quality of forest landscapes, and to determine the strength of effect of the features in the aesthetic value of the landscape. The methodology applied to assess forest landscapes took into account the following features: forest site humidity, age of forest, terrain slope, site index of stands, species composition of the tree layer, under-story cover, colour and composition, mosaic-like, as well as horizontal structure of the tree stands. The study was conducted in temperate forests located in Central-Eastern Europe - more precisely - in south-eastern Poland. In the investigated area the dominating tree species are: Pinus sylvestris L., Abies alba Mill., Fagus sylvatica L. and Quercus L. They cover 42.2\%, 20.8\%, 20.4\% and 6.5\% of the total forest area, respectively. The findings show that nearly $1 \%$ of the area of the examined forests within the relevant territory are characterized with very high landscape value, over $67 \%$ with high, $31 \%$ with medium, and less than $0.5 \%$ with low landscape value. A strong relationship occurs between terrain slope vs. aesthetic quality of landscape as well as forest site humidity vs. aesthetic quality of landscape. Weak effect was observed for site index of stands vs. aesthetic quality of landscape, and moderate relationship was identified in the case of the remaining features. The findings show the strength of relationship between the features of forests and the aesthetic quality of landscapes, consequently providing a tool for forest managers to develop attractive forest landscapes in selected areas.
\end{abstract}

Keywords: landscape values, landscape management, aesthetic quality of landscape, temperate forests, tourism, recreation, suburban forests.

\section{Introduction}

Looking through the Web of Science database one can find the earliest considerations related to landscape, dating from 1893 (Dennis, 1893). The author rightly points out the large scale aspect of the phenomenon: "A landscape covers several or many square miles"; and further its dynamic quality, such as in the image of: "...a flock of blackbirds suddenly flirting up from among the cattle in the pasture, circling about in a whimsical way, and then as suddenly dropping down again in the same place". Dennis also recognizes limitations of human eye in perceiving landscape. On the other hand the first information pertaining to forest landscapes appears in the database nearly 70 years later, yet it is not related to research focusing specifically on forest landscape which is only a backdrop for research into birds (Drozdova, Taskaeva, \& Dobrokhotov, 1960). The first publication reporting a study of landscape dominated by forests dates from 1972 and discusses changes in landscape resulting from human activity over the ages in Great Britain (Nicholls, 1972).
It is a well-known fact that forests positively impact the landscape quality of a given region and, apart from the lay of the land and surface waters, constitute the main component of landscape attractiveness (Dudek, 2012; Petrova et al., 2015; Senetra, 2015; Zhang, Deng, Ma, \& Sasaki, 2015). Moreover, compared with other ecosystems, forests generally feature higher rate of biological diversity (Gibson et al., 2011). Therefore, a risk of significant loss in biodiversity results from forest dieback (Martin, Newton, Cantarello, \& Evans, 2015), disturbances in forests (Fischer, Marshall, \& Camp, 2013) or inadequate forest management (Spiecker, 2003). It has been proved that in the spectator eyes more biodiverse landscapes are perceived as more attractive (Dudek, 2016b), is closely related to them (Bridgewater, 1988; Waldhardt, 2003; Thies \& Tscharntke, 1999 ) and with the ways a given area is used (Sala et al., 2000; Falcucci, Maiorano, \& Boitani, 2007; Haines-Young, 2009).

Temperate forests should be dominated by deciduous trees. Yet, until the late 1980s inconsiderate forest management focusing exclusively on profits from sales of lumber,

${ }^{\star}$ Corresponding author. E-mail: tdudek80@ur.edu.pl 
led to impoverishment of the tree-species composition in a significant part of European forests resulting in the dominance of coniferous tree-species. In the early 1990s, after the Rio de Janeiro Earth Summit, most European countries, including Poland, adopted a new approach, called sustainable forest management (SFM). One of six SFM criteria reads as follows: "Maintenance, conservation and appropriate enhancement of biological diversity in forest ecosystems"(...). The new model was linked with the necessity to alter the species composition of large-area monocultures mainly consisting of Pinus sylvestris L. and Picea abies L., as mentioned by Halme et al. (2013); on the other hand the positive influence of the adopted forest policy on landscapes in Poland was discussed by Mederski, Jakubowski and Karaszewski (2009). Despite these well-intended efforts in Europe coniferous forests extend far beyond the border of their natural habitat (Spiecker, 2003; Lorz et al., 2010). According to the Convention on Biological Diversity (CBD), landscape architects and designers also started to pay more attention to conservation and enhancement of biological diversity (Knaapen, Scheffer, \& Harms, 1992; Federowick, 1993; Sauer, 1993; Yahner, Korostoff, Johnson, Battaglia, \& Jones, 1995). The objective of $\mathrm{CBD}$ is to develop national strategies for the conservation and sustainable use of biological diversity, and enabling economic development and benefits for people. It combines traditional efforts aimed at environment conservation with economic objectives related to sustainable use of biological resources. The Convention recognizes the need for significant investments aimed at preservation of biological diversity, and it says that conservation will result in significant benefits for the environment, economy and the society.

The European Landscape Convention (a multilateral international agreement in force from 1 March 2004, approved by 35 states, including Poland) stipulates an obligation to identify and assess local landscapes. The objectives of the Convention include promotion of activities and organization of European cooperation related to landscape issues, mainly focusing on protection, planning and management. Indeed, more and more attention is given to these three issues. Alternative management methods are being discussed in relation to landscape (Gustafson \& Crow, 1996; Gustafson, Jay Roberts, \& Leefers, 2006; De Groot, Alkemade, Braat, Hein, \& Willemen, 2010). Similarly in forest management today there is more and more focus on forest landscape planning. As an example, in Finland it was proposed landscape ecological plans should be developed for all national forests (approx. 1/3 of all forests in Finland) (Kangas, Store, Leskinen, \& Mehtätalo, 2000). Concerns related to the loss of biological diversity in forest ecosystems, as well as potential economic benefits contribute to the increased attention to forest landscape management (Baskent \& Jordan, 1996). Furthermore, the need to precede forest management planning with assessment of forest landscapes was pointed out by Zanhg et al. (2015).
The author has made an attempt to answer the question which represents the purpose of the present study: is there a relationship between features and landscape values of tree stands and which of these features have the greatest impact on landscape aesthetics? The answer to this question provides grounds for detailed assessment of forest landscape and for implementing the objectives of the European Landscape Convention within the areas of Europe covered with forests.

\section{Material and methods}

The study was conducted in temperate forests located in Central-Eastern Europe, in south-eastern Poland $\left(21^{\circ}\right.$ $\left.25^{\prime}-22^{\circ} 30^{\prime} \mathrm{E}, 49^{\circ} 40^{\prime}-50^{\circ} 10^{\prime} \mathrm{N}\right)$. In the temperate zone of Europe forests occupy approx. 26\% of the area (Parviainen, 2005). In Poland forests cover $30.6 \%$ of the territory, out of which $81.2 \%$ are public, generally accessible forests (Zajączkowski et al., 2014). This means that woodiness in Poland is lower than the average for Europe (32.2\% excl. Russia). In the predominant part of Poland the forests are made of Pinus sylvestris L. (59.1\% of the forest area). On the whole conifers constitute $69.6 \%$. The most common deciduous trees are: Betula pendula Roth. and Betula pubescens Ehrh. (jointly 7.3\%), Quercus robur L. and Quercus petraea Liebl. (jointly 7.0\%), Fagus sylvatica L. (5.5\%) as well as Alnus glutinosa Gaertn. and Alnus incana (L.) Moench. (jointly 5.3\%). In terms of their age structure, most tree stands are $40-80$ years old (45\%), while the oldest tree stands, over 100 years of age, occupy $10 \%$ of the country's forest area (Zajączkowski et al., 2014).

The study was carried out in state-owned commercial forests administered by five forest districts (Strzyżów, Kołaczyce, Głogów, Leżajsk, Kańczuga). The total of 615 forest units were examined; they comprise an overall area of 16,360 ha which accounts for $25 \%$ of the forest areas managed by these five forest districts. In the area of the aforementioned forest districts the dominating tree species are: Pinus sylvestris L. (42.2\%), Abies alba Mill. (20.8\%), Fagus sylvatica L. (20.4\%) and Quercus L. (Quercus petraea Liebl. and Quercus robur L.) (6.5\%). The remaining 10.1\% of the area is covered by: Alnus glutinosa Gaertn., Betula pendula Roth., Carpinus betulus L., Larix decidua Mill., Acer pseudoplatanus L., and Fraxinus excelsior L. and to a lesser degree by other species.

Majority of the examined tree stands (42.38\%) represented the 5 th or older age class (classes defined every 20 years). Tree stands of the 4 th age class covered $36.26 \%$ of the area, 3rd class $-15.00 \%$, 2nd class $-5.25 \%$ and the youngest occupied only $1.11 \%$ of the area. The low proportion of tree stands representing two youngest age classes $(<40$ year) results from the long duration of forest renewal and acquisition of lumber from small-area timber felling sites.

In terms of the habitat humidity the ones described as fresh were most abundant ( $83 \%$ of the total area), followed by humid (16\%), and wet and marshy (1\%). No dry 
habitats were identified in the examined area. Exactly $33 \%$ of the examined tree stands grow in flat terrain, and the remaining stands cover terrains with varied orography; out of these $31 \%$ of the forest area is found on slopes with the inclination of $12^{\circ}, 35 \%$ slope in the range of $13-30^{\circ}$, $1 \%$ slope with an inclination $>30^{\circ}$. In terms of their horizontal structure, one-story tree stands were found to constitute a majority (65.07\%). Two-story and multi-story tree stands were found to occupy $18.51 \%$ and $16.42 \%$ of the area, respectively.

The selected forest units were assessed for their landscape values from the viewpoint of recreational use, taking into account the following features: forest site humidity, age of tree stand, terrain slope, site index of stands, species composition of the tree layer, understory cover, colour and composition, mosaic-like features determined mainly by the tree cover rate and the type of species mixture, as well as horizontal structure of the tree stands. The data used for assessment were acquired from Forest Management Plans elaborated and being in force for each relevant forest district. Assessment of the forest landscape from the internal viewpoint was conducted with the use of modified Rožkov's method (Ważyński, 1997), described and implemented by Dudek (2016b). When establishing landscape aesthetic classes, the proportions suggested by Rožkov were kept. He distinguished 5 forest landscape aesthetic classes, with class I comprising tree stands of the highest landscape value, while class $\mathrm{V}$ - of the lowest. Key to forest landscape valuation is presented in Table 1.

Subsequently, chi-squared test was conducted to investigate whether there was a relationship between the examined features (all of them were in nominal scale, except for the age class - in ordinal scale) and the aesthetic quality of the landscape (Table 3). In order to apply the test the combined forest units identified for high and very high landscape aesthetic value (1st and 2nd Class - ALC) were compared with the remaining tree stands (3rd and 4th Class - BLC; the 5th Class was not identified in the relevant area). If there was a relationship, its strength was examined with Cramer's V.

\section{Results}

The findings show that nearly $1 \%$ of the forest area within the relevant territory are characterized with very high landscape value, over $67 \%$ with high, $31 \%$ with medium, and less than $0.5 \%$ with low landscape value (Table 2). Yet, it should be remembered that landscape is dynamic.

Table 1. Key to forest landscape valuation (source: Dudek, 2016b)

\begin{tabular}{|c|c|c|c|}
\hline Number of points & & Evaluated feature of forests & Number of points \\
\hline $\begin{array}{l}1 \\
2 \\
3 \\
4 \\
5\end{array}$ & $\begin{array}{l}\text { Site index of stands } \\
\text { V } \\
\text { IV } \\
\text { III } \\
\text { II } \\
\text { I-I,5 }\end{array}$ & $\begin{array}{l}\text { Colour and composition } \\
\text { dry pine forest, single-species fir forest, single-species spruce forest } \\
\text { fresh pine forest, marshy, spruce forest } \\
\text { mixed coniferous forest, riparian, mixed forest } \\
\text { oak, beech, hornbeam forests }\end{array}$ & $\begin{array}{l}1 \\
2 \\
3 \\
4\end{array}$ \\
\hline $\begin{array}{l}2 \\
3\end{array}$ & $\begin{array}{l}\text { Undergrowth cover } \\
\text { lack or abundant } \\
\text { weeds } \\
\text { abundant weeds } \\
\text { turfy } \\
\text { mossy-baneberry } \\
\text { herbaceous }\end{array}$ & $\begin{array}{l}\text { Species composition of dendroflora } \\
\text { single-species tree stands } \\
\text { mixed tree stands ( } 2 \text { species), less than } 5 \text { tree flora species } \\
\text { single-species and mixed tree stands ( } 2 \text { species), 6-10 tree flora } \\
\text { species } \\
\text { mixed tree stands ( } 3-5 \text { species), less than } 10 \text { tree flora species } \\
\text { multi-species tree stands - over } 10 \text { species }\end{array}$ & $\begin{array}{l}1 \\
2 \\
3\end{array}$ \\
\hline $\begin{array}{l}1 \\
2 \\
3 \\
4 \\
5\end{array}$ & $\begin{array}{l}\text { Tree stand age } \\
\text { I age class } \\
\text { II age class } \\
\text { III age class } \\
\text { IV age class } \\
\geq \mathrm{V} \text { age class }\end{array}$ & $\begin{array}{l}\text { Horizontal structure of tree stands } \\
\text { single-layer tree stands, age class I-II no saplings and understory } \\
\text { one-story, age class I-II with weak saplings and understory } \\
\text { one-story with strong saplings and understory or } \geq \text { III age class } \\
\text { two-story } \\
\text { Multistory }\end{array}$ & $\begin{array}{l}1 \\
2 \\
3 \\
4 \\
5\end{array}$ \\
\hline $\begin{array}{l}1 \\
2 \\
3 \\
4 \\
5\end{array}$ & $\begin{array}{l}\text { Habitat humidity } \\
\text { marshy habitats } \\
\text { wet habitats } \\
\text { humid habitats } \\
\text { dry habitats } \\
\text { fresh habitats }\end{array}$ & $\begin{array}{l}\text { Terrain slope } \\
\text { very steep and precipitous slopes, slope }>30^{\circ} \\
\text { flat terrain } \\
\text { steep and precipitous slopes, slope } 13-30^{\circ} \\
\text { gentle slope, slope up to } 7^{\circ} \\
\text { inclined slope, slope } 8-12^{\circ}\end{array}$ & $\begin{array}{l}1 \\
2 \\
3 \\
4 \\
5\end{array}$ \\
\hline $\begin{array}{l}1 \\
2 \\
3 \\
4 \\
5\end{array}$ & \multicolumn{3}{|c|}{$\begin{array}{l}\text { Mosaic-like landscape features } \\
\text { tree stands of I-II age class, very dense with thick tree cover or very thin with thin tree cover } 0.1-0.2 \\
\text { I-II age class, tree cover of } 0.6-0.7 \\
\text { III and older, tree cover } \geq 0.7 \\
\text { tree cover of } 0.3-0.6 \text { with regular tree distribution, with thick saplings and understory is awarded } 3 \text { points } \\
\text { with tree cover of } 0.3-0.5 \text { with stands of trees, with thick saplings and understory, is awarded } 4 \text { points or fully } \\
\text { vital with tree cover of } 0.1-0.2\end{array}$} \\
\hline
\end{tabular}


Landscape will change, forests will "move" over time across classes of the landscape aesthetics, regardless whether these are commercial forests or areas no longer utilized. Such changes also depend on various disastrous phenomena, as a rule impossible to predict, e.g. hurricanes, fires, insect outbreaks. Indeed, during the initial period following their occurrence such phenomena always result in destruction of the landscape.

The present findings provide evidence for the existing relationship between the forest features and the aesthetic value of forest landscapes. A strong relationship (Cramer's $\mathrm{V}>0.5$ ) occurs between terrain slope vs. aesthetic quality of landscape as well as forest site humidity vs. aesthetic quality of landscape. Weak effect (Cramer's $\mathrm{V}<0.3$ ) was

Table 2. Forest landscape aesthetic classes for the object of research

\begin{tabular}{|l|c|c|c|}
\hline $\begin{array}{c}\text { Landscape aesthetic } \\
\text { class; total number } \\
\text { of points }\end{array}$ & $\begin{array}{c}\text { Number } \\
\text { of separate } \\
\text { forest stands }\end{array}$ & $\begin{array}{c}\text { Forest stands' } \\
\text { total area } \\
\text { [ha] }\end{array}$ & $\begin{array}{c}\% \\
\text { share }\end{array}$ \\
\hline $\begin{array}{l}\text { I very high landscape } \\
\text { value; 39-44 }\end{array}$ & 6 & 151.53 & 0.93 \\
\hline $\begin{array}{l}\text { II high landscape } \\
\text { value; 31-38 }\end{array}$ & 391 & 11046.28 & 67.52 \\
\hline $\begin{array}{l}\text { III moderate landscape } \\
\text { value; 22-30 }\end{array}$ & 216 & 5136.20 & 31.39 \\
\hline $\begin{array}{l}\text { IV low landscape } \\
\text { value; 13-21 }\end{array}$ & 2 & 26.43 & 0.16 \\
\hline $\begin{array}{l}\text { V very low landscape } \\
\text { value; up to 12 }\end{array}$ & 615 & 16360.44 & 100.00 \\
\hline Total & & & \\
\hline
\end{tabular}

Table 3. Relationship between landscape aesthetics and the examined forest features

\begin{tabular}{|l|l|c|}
\hline \multicolumn{2}{|c|}{$\begin{array}{c}\text { Statistics: tree stands covered (5, exception - color } 4) \times \\
\text { landscape aesthetic class (2) }\end{array}$} \\
\hline \multicolumn{1}{|c|}{ Forest features } & \multicolumn{1}{|c|}{ Pearson's Chi $^{2}$} & Cramér's V \\
\hline Color & $\begin{array}{l}66.2007 \\
\mathrm{df}=4, \mathrm{p}=0.00000\end{array}$ & 0.328 \\
\hline Site index of stands & $\begin{array}{l}26.7492 \\
\mathrm{df}=3, \mathrm{p}=0.00001\end{array}$ & 0.208 \\
\hline $\begin{array}{l}\text { Horizontal structure of } \\
\text { tree stands }\end{array}$ & $\begin{array}{l}94.3854 \\
\mathrm{df}=4, \mathrm{p}=0.00000\end{array}$ & 0.392 \\
\hline $\begin{array}{l}\text { Mosaic-like landscape } \\
\text { features }\end{array}$ & $\begin{array}{l}84.1920 \\
\mathrm{df}=4, \mathrm{p}=0.00000\end{array}$ & 0.370 \\
\hline Terrain slope & $\begin{array}{l}225.5625 \\
\mathrm{df}=4, \mathrm{p}=0.00000\end{array}$ & 0.606 \\
\hline Understory cover & $\begin{array}{l}119.0960 \\
\mathrm{df}=4, \mathrm{p}=0.00000\end{array}$ & 0.440 \\
\hline $\begin{array}{l}\text { Tree-species compo- } \\
\text { sition of overstory }\end{array}$ & $\begin{array}{l}77.9133 \\
\mathrm{df}=4, \mathrm{p}=0.00000\end{array}$ & 0.356 \\
\hline Tree stand age & $\begin{array}{l}77.8250 \\
\mathrm{df}=4, \mathrm{p}=0.00000\end{array}$ & 0.356 \\
\hline Forest site humidity & $\begin{array}{l}194.8539 \\
\mathrm{df}=4, \mathrm{p}=0.00000\end{array}$ \\
\hline
\end{tabular}

observed for site index of stands vs. aesthetic quality of landscape, and moderate relationship was found in the case of the remaining features (Table 3 ).

Tree stands of high aesthetic landscape value (ALC) occur mainly on slopes with an inclination of $13-30^{\circ}$ (here constituting $83 \%$ ) and an inclination of $8-12^{\circ}(92 \%)$. On the other hand tree stands with lower landscape value (BLC) were mainly identified in flat areas (here accounting for $71 \%$ ). BLC was recorded in $100 \%$ of the tree stands at the land inclination exceeding $30^{\circ}$, and ALC in $92 \%$ of the areas with inclination up to $7^{\circ}$ (Figure 1). However, in both cases the size of the sample was small.

Statistical verification of the findings showed significantly varied effects of habitat humidity in the landscape

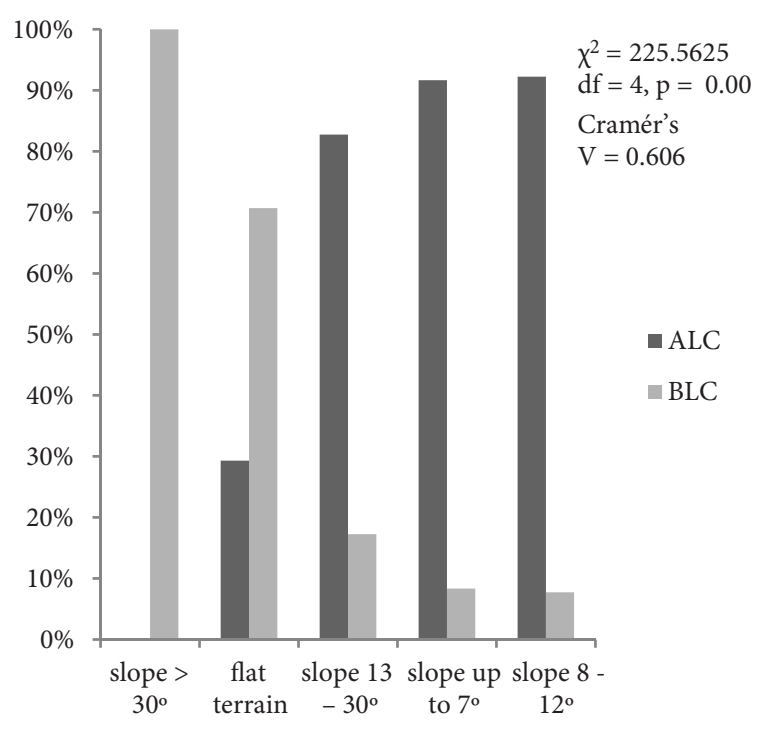

Figure 1. Frequency of tree stands representing the specific aesthetic landscape class at specific terrain inclination; ALC 1st and 2nd landscape aesthetic class; BLC - 3rd and 4th landscape aesthetic class

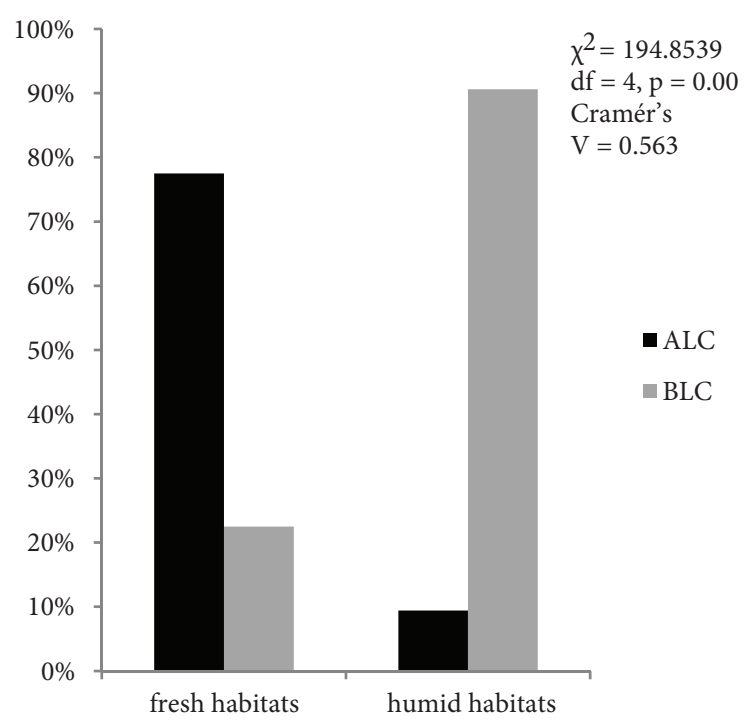

Figure 2. Frequency of tree stands representing the specific aesthetic landscape class at the selected forest sites 
values of the specific forest stands. Within fresh habitats majority of tree stands (77\%) present considerable landscape value (Figure 2). On the other hand in humid habitats tree stands with high landscape value were rather infrequent (ALC approx. 9\%).

The other forest stand features examined here were found to moderately correlate with aesthetic landscape classes, yet some relations are visible also in the case of these features (Figures 3-8).

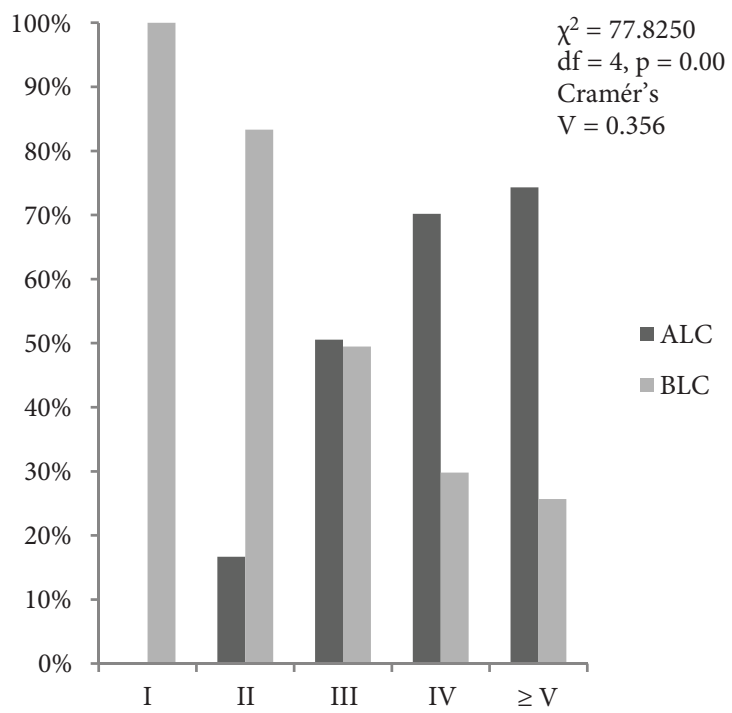

Figure 3. Frequency of tree stands representing the specific aesthetic landscape class relative to the age of the forest stand:

I - tree stands up to 20 years of age; II - 21-40 years;

III - 41-60 years; IV - 61-80 years; $\geq V$ over 81 years

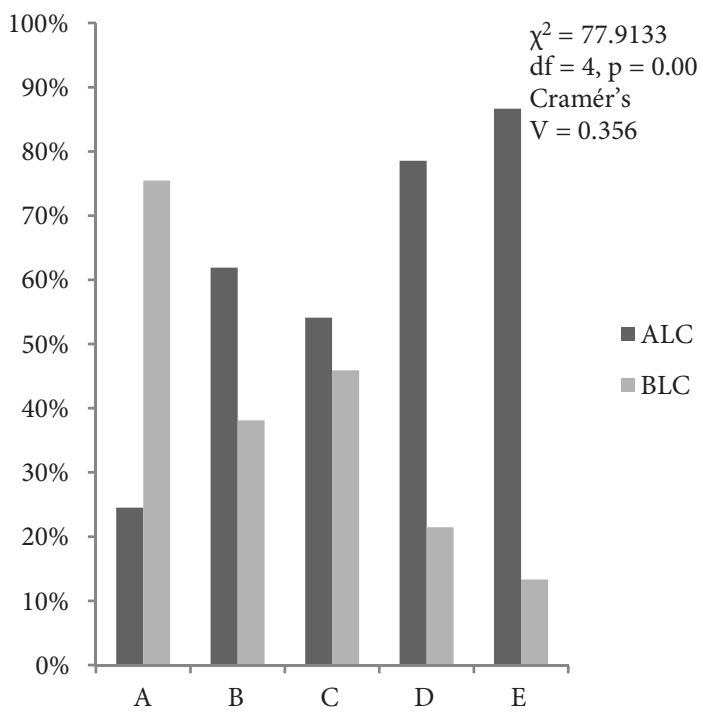

Figure 4. Frequency of tree stands representing the specific aesthetic landscape class relative to species composition of forest stand: A - single-species tree stands; B - mixed tree stands (2 species), less than 5 tree flora species; C - singlespecies and mixed tree stands ( 2 species); 6-10 tree flora species; D - mixed tree stands (3-5 species), less than 10 tree flora species; $\mathrm{E}$ - multi-species tree stands - over 10 species
As for the age of tree stands, we can notice that increasing rate of forests with greater landscape values corresponds with growing age. More specifically, in tree stands of up to 20 years of age ALC rate is $0 \%$, at $21-40$ years - ALC 17\%, at 41-60 years - ALC 50\%, at 61-80 years - ALC $70 \%$ and at 81 years and more - ALC 74\%.

If we take into account species composition of forest stands we can notice that single-species stands (monocultures) are generally found with lower landscape

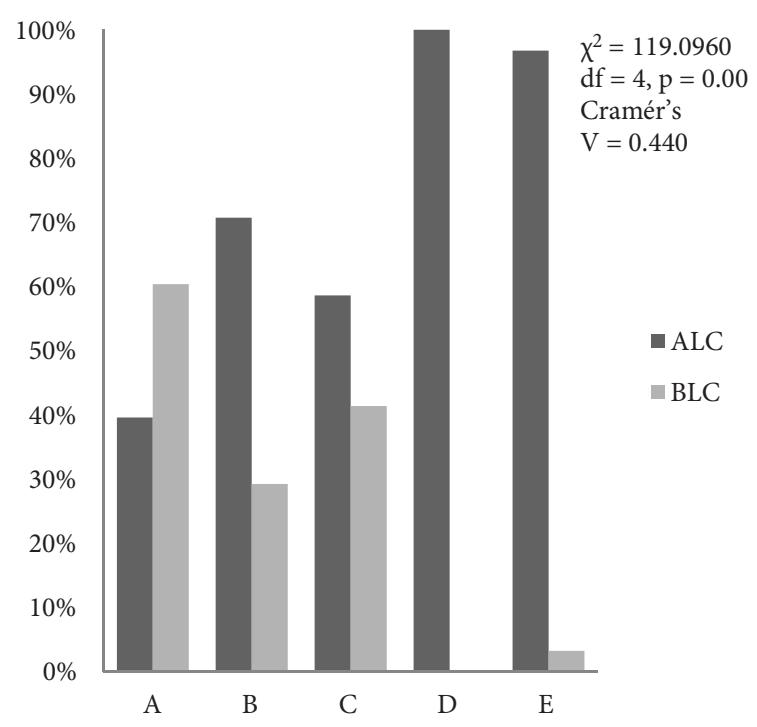

Figure 5. Frequency of tree stands representing the specific aesthetic landscape class relative to the undergrowth cover: A - lack or abundant weeds; B - abundant weeds; C - turfy; D - mossy-baneberry; E - herbaceous

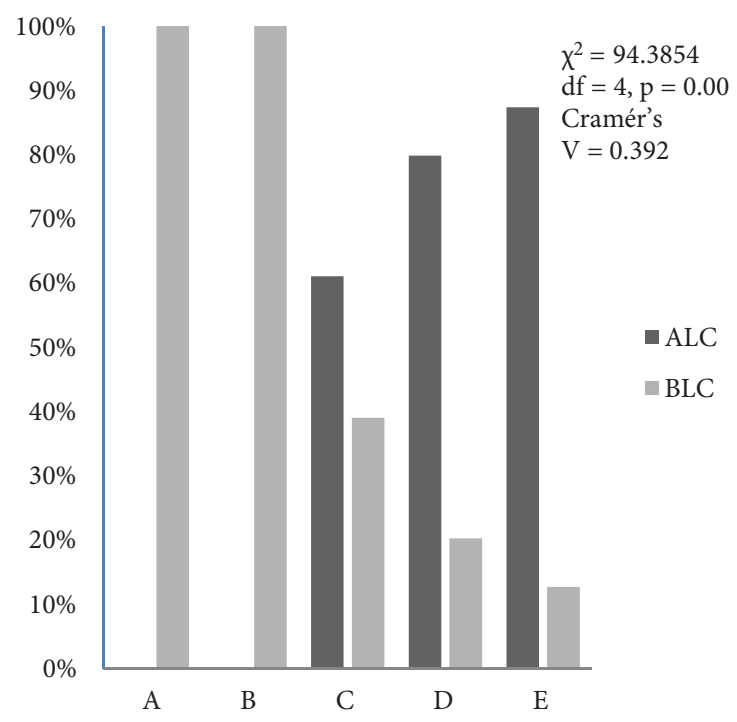

Figure 6. Frequency of tree stands representing the specific aesthetic landscape class relative to the vertical structure of forest: A - single-layer tree stands, age class I-II no saplings and understory; B - one-story, age class I-II with weak saplings and understory; C - one-story with strong saplings and understory or $\geq$ III age class; D - two-story; E - Multistory 


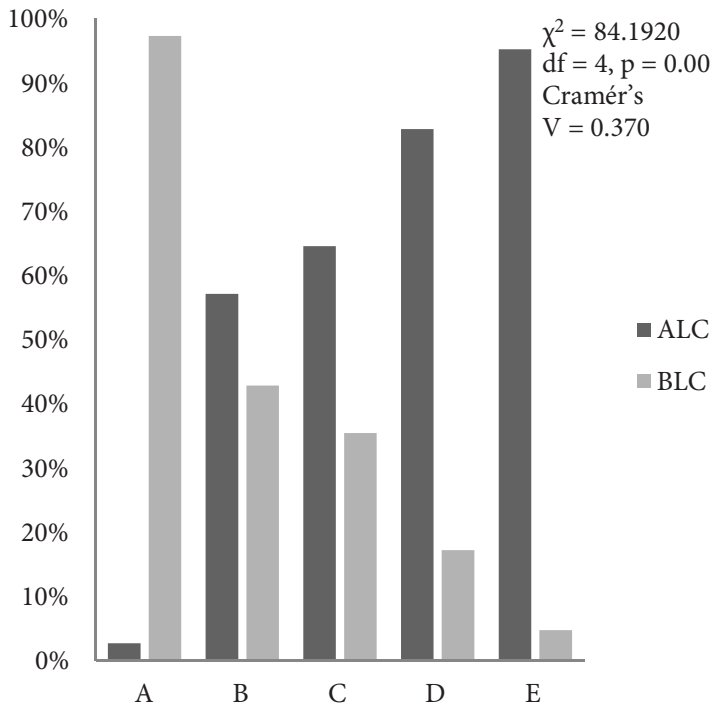

Figure 7. Frequency of tree stands representing the specific aesthetic landscape class relative to mosaic-like landscape features: A - tree stands of I-II age class, tree cover 0.1-0.2; $\mathrm{B}$ - I-II age class, tree cover of $0.6-0.7$; C - III and older, tree cover $\geq 0.7 ; \mathrm{D}$ - tree cover of $0.3-0.6$ with regular tree distribution, with thick saplings and understory is awarded 3 points; E - with tree cover of $0.3-0.5$ with stands of trees, with thick saplings and understory, is awarded 4 points or fully vital with tree cover of $0.1-0.2$

value $-75 \%$ of such stands are classified as BLC. On the other hand multi-species forest stands (with over 10 tree species) in vast majority (87\%) present with high landscape value (Figure 4 ).

If we examine undergrowth cover, we can see that $97 \%$ of the forest stands with herbaceous cover are characterized with high landscape value (ALC). Conversely, the tree stands with poorer landscape value (BLC) as a rule do not feature ground cover, or it is heavily infested with weed (Figure 5).

As for the vertical structure of forest the findings show that more complex structure beneficially affects the forest's landscape value. Majority of two-layer (79\% of these classified as ALC) and multilayer tree stands (87\% ALC) presented with higher landscape value (Figure 6).

If we examine mosaic-like landscape features, we can notice that almost all the forest stands with lower density of trees and species mixture, and with no dense undergrowth were classified as ALC (Figure 7, E - ALC 95\%).

As for the colour of forest, majority of oak, beech and mixed deciduous (mostly hornbeam) forests were classified as ALC $-84 \%$, while BLC is more often identified in monocultures of conifers (Figure 8).

\section{Discussion}

The acquired evidence shows that inclination of the terrain most significantly affects aesthetic value of forest landscape. The situation is similar in other types of landscape or in landscapes where forest constitutes one of its components (Dudek, 2012) which means it is not

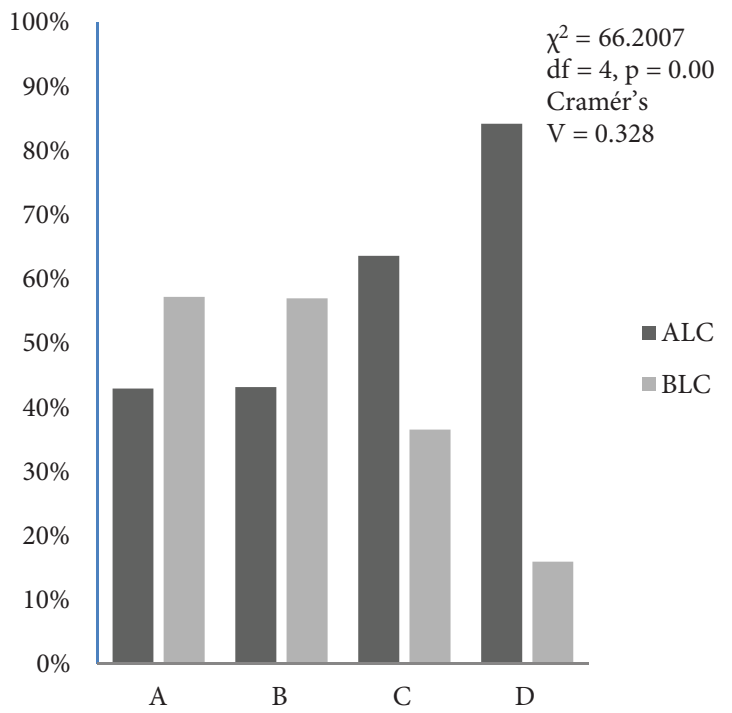

Figure 8. Frequency of tree stands representing the specific aesthetic landscape class relative to the colour - type of forest: A - dry pine forest, single-species fir forest, single-species spruce forest; B - fresh pine forest, marshy, spruce forest; C - mixed coniferous forest, riparian, mixed forest; D - oak, beech, hornbeam forests

examined from the inside, as a distinctive type of landscape. Conversely, a study assessing forest landscapes in Japan showed that it was surface waters that were the most important element enhancing landscape aesthetics (Zhang et al., 2015). Russian and Japanese research confirms that the most important element of landscapes for the Japanese is water, and for Russians topography (Petrova et al., 2015). The approach adopted in the present study did not take into account the impact of surface waters on the quality of forest landscape; yet the present study did investigate such effect of forest site humidity and showed a strong relationship between the latter factor and the aesthetic value of forest landscapes (Table 3), the most attractive being the forests growing in fresh habitats and the least attractive are those in marshy habitats. Hence, attractive quality of forest landscapes depends mainly on the lay of the land and forest site humidity, and only to a lesser degree on the plant associations dominated by trees and tree stand structure. Due to the weak relationship between site index of stands and landscape aesthetics it can be recommended that this feature should be disregarded in future assessments of forest landscape. On the other hand Tahvanainen, Tyrväinen, Ihalainen, Vuorela and Kolehmainen (2001) emphasize that the picturesque value of forests is affected by a number of factors, including species composition, forest structure and forest management. Research has shown that near-natural forests with no traces of human activity are recognized as more beautiful by individuals living in rural and suburban areas while opposite opinion is expressed by those living in urban areas. Jankovska, Straupe, Brumelis, Donis, and Kupfere (2014) argue that 
openness of forest stand affects to improve the landscape aesthetic value. According to Shifley, Thompson, Dijak, Larson, and Millspaugh (2006) forest management and intensity of forest exploitation are the main factors affecting forest landscapes. Radeloff et al. (2006) also highlighted the relation between forest management and landscape. It was shown that cut unit size had the greatest impact. Yet the other two components of management examined in the study, i.e. minimum harvest age and target species for management, were also of importance. On the other hand Janeczko (2012), in her study of public preferences related to shaping of forest landscape along roads, came to the conclusion that forest management only mildly affects shaping of landscapes, and in this case the important factors mainly include engineering operations connected with construction of roads (overpasses, embankments, earthworks).

In the assessed area the age structure of tree stands with high proportion of old forests favourably impacts perception of forest landscapes and is also beneficial from the viewpoint of recreational use of forests (Kikulski, 2006; Dudek, 2017). Similarly, the distribution of the tree stands in terms of forest site humidity is favourable. Majority of the examined tree stands grow in fresh habitats. Other studies show that Polish people indeed prefer older tree stands growing in fresh habitats (Skłodowski \& Gołos, 2015), like in other regions of Europe (Great Britain, Nordic Region, Central Europe and Iberia), where (age related) size of trees was shown as the major factor affecting positive perception of forest (Edwards et al., 2012).

The term "forest landscape", frequently used in the literature, can be understood as landscape in which forest is a dominating component (e.g. Nicholls, 1972; Turner, Cohen, \& Kennedy, 2000; Cottam, Robinson, Heske, Brawn, \& Rowe, 2009). Forest landscape is also characterized briefly by a specific type of forest, e.g. pine forest landscape, riparian forest landscape, etc. (Edman, Angelstam, Mikusiński, Roberge, \& Sikora, 2011). On the other hand the present study has adopted the approach in which forest landscape is understood as a space limited on all sides by the wall of forest. By crossing the wall of forest we enter the interior of forest landscape. One of the main reasons why in many places worldwide people visit forests is the opportunity to enjoy attractive scenery (Hansson, Külvik, Bell, \& Maikov, 2012; Paletto, Ferretti, Cantiani, \& De Meo, 2012; Zhang et al., 2015; Tyrväinen, Silvennoinen, \& Hallikaine, 2016). Due to these forest areas selected as a result of forest landscape assessment should be managed in ways making it possible to maintain or upgrade landscape value of the tree stands. In suburban forests in Finland the public supports management operations which contribute to development of the most beautiful forest landscapes (Horne, Boxall, \& Adamowicz, 2005). Grilli, Paletto, and De Meo (2014) and De Meo, Paletto, and Cantiani (2015) point out that greater emphasis on enhancing forest landscapes, particularly in areas attracting large numbers of visitors, is in the interest not only of the local community but also of the entire region's economy. Gios and Clauser (2009) argue that the greatest benefits from attractive landscapes are gained by: hoteliers, shopkeepers, service firms. Such entities should participate in the costs of creating attractive landscapes, yet this requires adequate policies and regulations. Scientists also recognize the need for the involvement of the societies in planning forest landscapes (Saito, Imura, Okamoto, \& Fujiwara, 2007; De Meo, Ferretti, Frattegiani, Lora, \& Paletto, 2013). Likewise, Dudek (2016a) claims that forests may play a number of functions and retain landscape stability if the forests designated primarily for recreation are selected by specialists, who also take into account preferences of a given region's residents.

The method involves rating of numerous features of forest stands (see Table 1). The features as examined and described in each forest stand by a team in charge of forest development, once in 10 years; the findings acquired by such teams are accessible to anyone in forest district offices. Therefore, in comparison to traditional landscape assessment procedures (cf.: Johnson, Brunson, \& Kimura, 1994), the applied method enables cost and time effective assessment of relatively large areas of forest landscapes (16.000 ha in the present study). The present findings show the strength of relationship between features of forests and forest landscape aesthetic value, consequently providing a tool for forest managers to develop attractive forest landscapes in selected forest areas.

Moreover, the findings show that the features most significantly impacting forest landscape aesthetics (mainly associated with abiotic environment of forest ecosystem), can only be changed to a very small degree. Indeed, we cannot give shape to the terrain, change forest site humidity, and in part understory cover (by reducing density of stands we can increase the number of plants in undergrowth, affect their condition or support occurrence of species requiring more light, yet we cannot influence the potential species composition which results from habitat quality). Nevertheless, in an area with uniform terrain and forest site humidity we can transform forest landscape by means of silvicultural measures which may alter most of the assessed features of tree stands (tree-species composition in over- and /or understory, vertical and horizontal tree-stand structure, and age structure, colour).

\section{Conclusions}

The approach applied in the study enables identification of forests with high landscape value, as a result of which it is possible to implement the main assumptions of the European Landscape Convention, i.e. planning, management and protection of the most valuable landscapes within the areas of Europe covered with forests.

To protect and enhance landscape value of the selected forest units the following operations should be implemented:

- drawing up landscape maps of forests taking into account landscape aesthetics classes, based on previous forest landscape assessments, 
- establishing multi-species tree stands with dominating deciduous trees which are more typical for temperate forests, with group mixture of species,

- introducing extended felling age, with acquisition of timber either in very small areas or based on single-tree selection (individual trees are cut without significantly thinning the forest stand; this harvesting method produces hardly visible changes to the landscape, yet it is linked with higher costs of timber acquisition since the load is scattered in a large area) and taking advantage of the natural processes of forest renewal,

- in the case of species with larger amplitude of sunlight requirements, growing two- or even multistory tree-stands, and in the case of species with higher sunlight demand, under-planting in groups which total area does not exceed $10 \%$ of the area of the forest unit in matter.

\section{References}

Baskent, E. Z., \& Jordan, G. A. (1996). Designing forest management to control spatial structure of landscapes. Landscape and Urban Planning, 34, 55-74.

https://doi.org/10.1016/0169-2046(95)00200-6

Bridgewater, P. B. (1988). Biodiversity and landscape. EarthScience Reviews, 25, 485-491.

https://doi.org/10.1016/0012-8252(88)90015-3

Cottam, M. R., Robinson, S. K., Heske, E. J., Brawn, J. D., \& Rowe, K. C. (2009). Use of landscape metrics to predict avian nest survival in a fragmented midwestern forest landscape. Biological Conservation, 142, 2464-2475.

https://doi.org/10.1016/j.biocon.2009.05.017

De Groot, R. S., Alkemade, R., Braat, L., Hein, L., \& Willemen, L. (2010). Challenges in integrating the concept of ecosystem services and values in landscape planning, management and decision making. Ecological Complexity, 7, 260-272.

https://doi.org/10.1016/j.ecocom.2009.10.006

De Meo, I., Ferretti, F., Frattegiani, M., Lora, C., \& Paletto, A. (2013). Public participation GIS to support a bottom-up approach in forest landscape planning. iForest - Biogeosciences and Forestry, 6, 347-352. https://doi.org/10.3832/ifor0917-006

De Meo, I., Paletto, A., \& Cantiani, M. G. (2015). The attractiveness of forests: preferences and perceptions in a mountain community in Italy. Annals of Forest Research, 58, 145-156. https://doi.org/10.15287/afr.2015.308

Dennis, W. (1893). Can we see the Picture in the landscape? Science, $n s$-22(559), 213.

https://doi.org/10.1126/science.ns-22.559.213

Drozdova, Y. V., Taskaeva, E. Z., \& Dobrokhotov, B. P. (1960). Some data on birds as tick-hosts at the mountain-forest landscapes of the N.E. Altai. Ornitologia, 3, 190-199.

Dudek, T. (2012). Ocena walorów krajobrazowych okolic Rzeszowa. Acta Scientiarum Polonorum, Administratio Locorum, 11, 65-71 (in Polish).

Dudek, T. (2016a). Needs of the local population related to development of forests for recreational purposes: example of south-eastern Poland. Journal of Forest Science, 62, 35-40. https://doi.org/10.17221/99/2015-JFS

Dudek, T. (2016b). Valuation of forest landscape in the Czarnorzecko-Strzyżowski Landscape Park. Space \& Form, 26, 187-200. Retrieved from http://www.pif.zut.edu.pl//im-
ages/pdf/pif-26/DOI\%2010_21005\%20pif_2016_26_D-03_ Dudek.pdf

Dudek, T. (2017). Recreational potential as an indicator of accessibility control in protected mountain forest areas. Journal of Mountain Science, 14(7), 1419-1427. https://doi.org/10.1007/s11629-016-4018-Z

Edman, T., Angelstam, P., Mikusiński, G., Roberge, J. M., \& Sikora, A. (2011). Spatial planning for biodiversity conservation: Assessment of forest landscapes' conservation value using umbrella species requirements in Poland. Landscape and Urban Planning, 102, 16-23.

https://doi.org/10.1016/j.landurbplan.2011.03.004

Edwards, D., Jay, M., Jensen, F. S., Lucas, B., Marzano, M., Montagné, C., Peace, A., \& Weiss, G. (2012). Public preferences for structural attributes of forests: Towards a pan-European perspective. Forest Policy and Economics, 19, 12-19.

https://doi.org/10.1016/j.forpol.2011.07.006

Falcucci, A., Maiorano, L., \& Boitani, L. (2007). Changes in land-use/land-cover patterns in Italy and their implications for biodiversity conservation. Landscape Ecology, 22, 617-631. https://doi.org/10.1007/s10980-006-9056-4

Federowick, J. M. (1993). A landscape restoration framework for wildlife and agriculture in the rural landscape. Landscape and Urban Planning, 27, 7-17. https://doi.org/10.1016/0169-2046(93)90024-8

Fischer, A., Marshall, P., \& Camp, A. (2013). Disturbances in deciduous temperate forest ecosystems of the northern hemisphere: their effects on both recent and future forest development. Biodiversity and Conservation, 22, 1863-1893.

https://doi.org/10.1007/s10531-013-0525-1

Gibson, L., Lee, T. M., Koh, L. P., Brook, B. W., Gardner, T. A., Barlow, J., Peres, C. A., Bradshaw, C. J. A., Laurance, W. F., Lovejoy, T. E., \& Sodhi, N. S. (2011). Primary forests are irreplaceable for sustaining tropical biodiversity. Nature, 478, 378-381. https://doi.org/10.1038/nature10425

Gios, G., \& Clauser, O. (2009). Forest and tourism: economic evaluation and management features under sustainable multifunctionality. iForest - Biogeosciences and Forestry, 2, 192-197. https://doi.org/10.3832/ifor0514-002

Grilli, G., Paletto, A., \& De Meo, I. (2014). Economic valuation of forest recreation in an alpine valley. Baltic Forestry, 20, 167-175. Retrieved from https://www.balticforestry.mi.lt/bf/ PDF_Articles/2014-20[1]/Economic\%20Valuation\%20of\%20 Forest\%20Recreation\%20in\%20an\%20Alpine\%20Valley.pdf

Gustafson, E. J., \& Crow, T. R. (1996). Simulating the effects of alternative forest management strategies on landscape structure. Journal of Environmental Management, 46, 77-94. https://doi.org/10.1006/jema.1996.0008

Gustafson, E. J., Jay Roberts, L., \& Leefers, L. A. (2006). Linking linear programming and spatial simulation models to predict landscape effects of forest management alternatives. Journal of Environmental Management, 81, 339-350. https://doi.org/10.1016/j.jenvman.2005.11.009

Haines-Young, R. (2009). Land use and biodiversity relationships. Land Use Policy, 26(S1), S178-S186. https://doi.org/10.1016/j.landusepol.2009.08.009

Halme, P., Allen, K. A., Auniņš, A., Bradshaw, R. H. W., Brūmelis, G., Čada, V., Clear, J. L., Eriksson, A., Hannon, G., Hyvärinen, E., Ikauniece, S., Iršènaite, R., Jonsson, B. G., Junninen, K., Kareksela, S., Komonen, A., Kotiaho, J. S., Kouki, J., Kuuluvainen, T., Mazziotta, A., Mönkkönen, M., Nyholm, K., Oldén, A., Shorohova, E., Strange, N., Toivanen, T., VanhaMajamaa, I., Wallenius, T., Ylisirniö, A., \& Zin, E. (2013). Challenges of ecological restoration: lessons from forests in 
northern Europe. Biological Conservation, 167, 248-256. https://doi.org/10.1016/j.biocon.2013.08.029

Hansson, K., Külvik, M., Bell, S., \& Maikov, K. (2012). A preliminary assessment of preferences for Estonian natural forests. Baltic Forestry, 18, 299-315. Retrieved from https:// www.balticforestry.mi.lt/bf/PDF_Articles/2012-18[2]/Hansson_2012\%2018(2)_299_315.pdf

Horne, P., Boxall, P. C., \& Adamowicz, W. L. (2005). Multipleuse management of forest recreation sites: a spatially explicit choice experiment. Forest Ecology and Management, 207, 189199. https://doi.org/10.1016/j.foreco.2004.10.026

Janeczko, E. (2012). Preferencje społeczne w zakresie kształtowania krajobrazu leśnego w sąsiedztwie dróg. Sylwan, 156, 12-18 (in Polish).

Jankovska, I., Straupe, I., Brumelis, G., Donis, J., \& Kupfere, L. (2014). Urban forests of Riga, Latvia - pressures, naturalness, attitudes and management. Baltic Forestry, 20, 342-351. Retrieved from https://www.balticforestry.mi.lt/bf/PDF_Articles/2014-20[2]/Urban\%20forests\%20of\%20Riga-LatviaPressures-Naturalness-Atitudes\%20and\%20management.pdf

Johnson, R. L., Brunson, M. W., \& Kimura, T. (1994). Using image-capture technology to assess scenic value at the urban/ forest interface: a case study. Journal of Environmental Management, 40, 183-195. https://doi.org/10.1006/jema.1994.1014

Kangas, J., Store, R., Leskinen, P., \& Mehtätalo, L. (2000). Improving the quality of landscape ecological forest planning by utilising advanced decision-support tools. Forest Ecology and Management, 132, 157-171. https://doi.org/10.1016/S0378-1127(99)00221-2

Kikulski, J. (2006). Przydatność wybranych obszarów leśnych Bolimowskiego Parku Krajobrazowego do turystyki i rekreacji. Sylwan, 6, 40-49 (in Polish).

Knaapen, J. P., Scheffer, M., \& Harms, B. (1992). Estimating habitat isolation in landscape planning. Landscape and Urban Planning, 23, 1-16. https://doi.org/10.1016/0169-2046(92)90060-D

Lorz, C., Fürst, C., Galic, Z., Matijasic, D., Podrazky, V., Potocic, N., Simoncic, P., Strauch, M., Vacik, H., \& Makeschin, F. (2010). GIS-based probability assessment of natural hazards in forested landscapes of central and South-Eastern Europe. Environmental Management, 46, 920-930. https://doi.org/10.1007/s00267-010-9508-0

Martin, P. A., Newton, A. C., Cantarello, E., \& Evans, P. (2015). Stand dieback and collapse in a temperate forest and its impact on forest structure and biodiversity. Forest Ecology and Management, 358, 130-138.

https://doi.org/10.1016/j.foreco.2015.08.033

Mederski, P. S., Jakubowski, M., \& Karaszewski, Z. (2009). The Polish landscape changing due to forest policy and forest management. iForest - Biogeosciences and Forestry, 2, 140-142. https://doi.org/10.3832/ifor0503-002

Nicholls, P. H. (1972). On the evolution of a forest landscape. Transactions of the Institute of British Geographers, 56, 57-76. https://doi.org/10.2307/621542

Paletto, A., Ferretti, F., Cantiani, P., \& De Meo, I. (2012). Multifunctional approach in forest landscape management planning: an application in Southern Italy. Forest Systems, 21, 6880. https://doi.org/10.5424/fs/2112211-11066

Parviainen, J. (2005). Virgin and natural forests in the temperate zone of Europe. Forest Snow and Landscape Research, 79, 9-18. Retrieved from http://www.issw.ch/dienstleistungen/ publikationen/pdf/6746.pdf

Petrova, E. G., Mironov, Y. V., Aoki, Y., Matsushima, H., Ebine, S., Furuya, K., Petrova, A., Takayama, N., \& Ueda, H. (2015).
Comparing the visual perception and aesthetic evaluation of natural landscapes in Russia and Japan: cultural and environmental factors. Progress in Earth and Planetary Science, 2, 1-12. https://doi.org/10.1186/s40645-015-0033-X

Radeloff, V. C., Mladenoff, D. J., Gustafson, E. J., Scheller, R. M., Zollner, P. A., He, H. S., \& Akcakaya, H. R. (2006). Modeling forest harvesting effects on landscape pattern in the Northwest Wisconsin Pine Barrens. Forest Ecology and Management, 236, 113-126. https://doi.org/10.1016/j.foreco.2006.09.007

Saito, K., Imura, K., Okamoto, T., \& Fujiwara, A. (2007). Historical forest landscape reconstruction using continuous forest management data from 1931 to 2001 at Tokyo University forest in Chichibu, central Japan. Journal of Forest Research, 12, 193-200. https://doi.org/10.1007/s10310-007-0010-3

Sala, O. E., Chapin, F. S., Armesto, J. J., Berlow, E., Bloomfield, J., Dirzo, R., Huber-Sanwald, E., Huenneke, L. F., Jackson, R. B., Kinzig, A., Leemans, R., Lodge, D. M., Mooney, H. A., Oesterheld, M., LeRoy Poff, N., Sykes, M. T., Walker, B. H., Walker, M., \& Wall, D. H. (2000). Global biodiversity scenarios for the year 2100. Science, 287, 1770-1774.

https://doi.org/10.1126/science.287.5459.1770

Sauer, L. (1993). The North Woods of Central Park. Landscape Architecture, 83, 55-57.

Senetra, A. (2015). Las jako istotny komponent przestrzeni w aspekcie opracowywania map wartości krajobrazów wiejskich. Sylwan, 159, 757-766 (in Polish).

Shifley, S. R., Thompson, F. R., Dijak, W. D., Larson, M. A., \& Millspaugh, J. J. (2006). Simulated effects of forest management alternatives on landscape structure and habitat suitability in the Midwestern United States. Forest Ecology and Management, 229, 361-377.

https://doi.org/10.1016/j.foreco.2006.04.030

Skłodowski, J., \& Gołos, P. (2015). Preferowany typ drzewostanu i czynniki decydujące o atrakcyjności turystycznej drzewostanu w opinii społecznej. Sylwan, 159, 747-756 (in Polish).

Spiecker, H. (2003). Silvicultural management in maintaining biodiversity and resistance of forests in Europe - temperate zone. Journal of Environmental Management, 67, 55-65. https://doi.org/10.1016/S0301-4797(02)00188-3

Tahvanainen, L., Tyrväinen, L., Ihalainen, M., Vuorela, N., \& Kolehmainen, O. (2001). Forest management and public perceptions - visual versus verbal information. Landscape and Urban Planning, 53, 53-70.

https://doi.org/10.1016/S0169-2046(00)00137-7

Thies, C., \& Tscharntke, T. (1999). Landscape structure and biological control in agro-ecosystems. Science, 285, 893-895. https://doi.org/10.1126/science.285.5429.893

Turner, D. P., Cohen, W. B., \& Kennedy, R. E. (2000). Alternative spatial resolutions and estimation of carbon flux over a managed forest landscape in Western Oregon. Landscape Ecology, 15, 441-452. https://doi.org/10.1023/A:1008116300063

Tyrväinen, L., Silvennoinen, H., \& Hallikainen, V. (2016). Effect of the season and forest management on the visual quality of the nature-based tourism environment: a case from Finnish Lapland. Scandinavian Journal of Forest Research, 1-11. https://doi.org/10.1080/02827581.2016.1241892

Waldhardt, R. (2003). Biodiversity and landscape-summary, conclusions and perspectives. Agriculture, Ecosystems \& Environment, 98, 305-309. https://doi.org/10.1016/S0167-8809(03)00090-2

Ważyński, B. (1997). Urządzanie i zagospodarowanie lasu dla potrzeb turystyki i rekreacji. Wydawnictwo Akademii Rolniczej w Poznaniu (in Polish). 
Yahner, T. G., Korostoff, N., Johnson, T. P., Battaglia, A. M., \& Jones, D. R. (1995). Cultural landscapes and landscape ecology in contemporary greenway planning, design and management: a case study. Landscape and Urban Planning, 33, 295316. https://doi.org/10.1016/0169-2046(94)02024-A

Zajączkowski, G., Jabłoński, M., Jabłoński, T., Małecka, M., Kowalska, A., Małachowska, J., \& Piwnicki, J. (2014). Raport o stanie lasów w Polsce w 2013. Centrum Informacyjne Lasów Państwowych (in Polish).

Zhang, T., Deng, S., Ma, Q., \& Sasaki, K. (2015). Evaluations of landscape locations along trails based on walking experiences and distances traveled in the Akasawa forest therapy base, central Japan. Forests, 6, 2853-2878.

https://doi.org/10.3390/f6082853 